\title{
LONGITUDINAL DISTRIBUTION OF COPEPODA POPULATIONS IN THE TRANSITION ZONE OF PARANAPANEMA RIVER AND JURUMIRIM RESERVOIR (SÃO PAULO, BRAZIL) AND INTERCHANGE WITH TWO LATERAL LAKES
}

\author{
CASANOVA, S. M. C. and HENRY, R. \\ Departamento de Zoologia, Instituto de Biociências, Universidade do Estado de São Paulo (UNESP), \\ CEP 18618-000, Rubião Júnior, Botucatu, SP, Brazil \\ Correspondence to: Raoul Henry, Departamento de Zoologia, Instituto de Biociências, Universidade do Estado de \\ São Paulo (UNESP), CEP 18618-000, Rubião Júnior, Botucatu, SP, Brazil, e-mail: rhenry@ibb.unesp.br \\ Received August 27, 2002 - Accepted February 24, 2003 - Distributed February 29, 2004
}

(With 8 figures)

\begin{abstract}
Longitudinal changes in composition, abundance, and distribution of copepods were studied at the transition zone of Paranapanema River-Jurumirim Reservoir (SP, Brazil). The interchange of biotic material between marginal lakes and the river system was also examined. Water samples were obtained from 6 stations along a stretch of $13 \mathrm{~km}$ of the Paranapanema River, from an upstream reach with high water velocity up to the river mouth into Jurumirim Reservoir. Two other sites in lateral lakes were also sampled. Nine copepod taxa were identified: 3 calanoids (Argyrodiaptomus furcatus Sars, Notodiaptomus iheringi Wright, and N. conifer Sars) and 6 cyclopoids (Eucyclops Claus, Microcyclops Claus, Mesocyclops longisetus Thiébaud, Thermocyclops decipiens Fischer, T. minutus Lowndes, and Paracyclops Claus). Harpacticoids were also collected. Calanoid and cyclopoid nauplii and copepodids, and harpacticoids were the most abundant organisms. In general, there was a longitudinal decrease in copepod abundance, whereas an increase was detected near the lakes. The abundance of most copepods was inversely correlated with current velocity and suspended solids. Higher abundance was observed in the river main course during the rainy season, during which there is a higher connectivity between the lakes and the main river. This promotes exportation of biologic material from marginal lakes to the river system, a biotic exchange reflecting the importance of marginal lakes to the river community structure.
\end{abstract}

Key words: Copepoda, longitudinal distribution, river, lakes, floodplain.

\section{RESUMO}

\section{Distribuição longitudinal de Copepoda na região de transição rio-reservatório (rio Paranapanema-Represa de Jurumirim, SP) e influência de duas lagoas laterais}

O presente estudo foi realizado na zona de desembocadura do rio Paranapanema, na Represa de Jurumirim, visando a verificar as mudanças longitudinais na composição, abundância e distribuição dos Copepoda e a analisar a influência de lagoas laterais na exportação de material biótico para o rio. Foram amostrados 6 pontos no rio (trecho de $13 \mathrm{~km}$ ), desde um local mais a montante, com alta velocidade da correnteza, até um local com características mais lênticas, na desembocadura do rio na represa, além de duas lagoas conectadas ao rio. Foram identificados 9 taxa: 3 Calanoida (Argyrodiaptomus furcatus Sars, Notodiaptomus iheringi Wright e N. conifer Sars) e 6 Cyclopoida (Eucyclops Claus, Microcyclops Claus, Mesocyclops longisetus Thiébaud, Thermocyclops decipiens Fischer, T. minutus Lowndes e Paracyclops Claus), além de representantes da ordem Harpacticoida. 
Os organismos mais abundantes foram as fases de desenvolvimento nauplius e copepoditos, de Calanoida e Cyclopoida e os Harpacticoida. De forma geral, observou-se diminuição na abundância dos Copepoda, do ponto 1 ao ponto 5, aumentando, porém, no ponto 6 e nas lagoas marginais. A maioria dos Copepoda mostrou relação inversa com a velocidade da corrente e o material em suspensão. Sazonalmente, as maiores abundâncias no canal do rio foram observadas no período chuvoso, refletindo a importância das lagoas laterais na estrutura da comunidade do rio, visto que nesse período ocorre maior conexão entre os ambientes, acarretando a exportação de material biológico das lagoas para o rio.

Palavras-chave: Copepoda, distribuição longitudinal, rios, lagoas, planície de inundação.

\section{INTRODUCTION}

In rivers, zooplankton density is usually believed to be low (Greenberg, 1964; Hynes, 1970). However, there are studies reporting high densities of zooplankton in lotic environments, both regulated and unregulated (Winner, 1975; Steveninck et al., 1992; Kobayashi et al., 1998).

Factors controlling spatial and temporal variations in zooplankton density in river systems have been focused on to determine the effects of abiotic factors on lotic communities, but also to show the importance of zooplankton in nutrient transfering and recycling (especially carbon, phosphorus, and nitrogen) in aquatic systems (Kobayashi et al., 1998).

Several studies on zooplankton longitudinal distribution in lotic systems have evidenced an increasing gradient downstream of several community attributes such as biomass, density, diversity, and richness (Hutchinson, 1939; Greenberg, 1964; Drago \& Vassalo, 1980; Armengol et al., 1988; Jose de Paggi, 1983; Saunders \& Lewis, 1988, 1989; Paggi \& Jose de Paggi, 1990; Vasquez \& Rey, 1989; Velho et al., 2001). These parameters were mainly related to the increase of phytoplankton densities and primary productivity; to environmental factors like temperature, suspended solids, and current velocity; and to hydrological processes.

Zooplankton community structure in lotic systems may also be affected by interactions between lateral lakes and river and its, especially in the rainy season when connectivity is intense. In rivers, annual fluctuations of water level show a positive relationship with specific richness resulting from the addition of populations coming from lentic water bodies of the floodplain (Paggi \& Jose de Paggi, 1990). In floodplain river systems, continuous interchanges of zooplankton fauna of marginal lakes, channels, and river occurs as a result of the degree of connection between environments which are submitted to highly variable hydrological cycles during the year (Lansac-Tôha et al., 1997).

The aim of this study is to show how the longitudinal distribution of copepod populations varies in the transition zone between the Paranapanema River and the Jurumirim Reservoir, where the water level is lower than in the floodplains. The copepoda populations in two lateral lakes was also studied to compare the structure of lotic and lentic communities. In addition, hydrologic and abiotic factors were examined as potential controlling factors of the copepod community structure.

\section{MATERIAL AND METHODS}

Samples were obtained from six stations distributed along $13 \mathrm{~km}$ starting from upstream towards the Paranapanema River mouth into Jurumirim Reservoir, in the river-reservoir transition zone-. In this region, there are several lateral lakes, with either temporary or permanent connections with the river system. In January, April, August, and October of 1998, physical and chemical water parameters and zooplankton samples were obtained from surface water of 6 sites along the river channel (P1 to P6) and from the limnetic zone of two lateral lakes (P7, Coqueiral Lake; P8, Camargo Lake) (Fig. 1).

For quantitative analysis of the copepods, three samples of 300 liters were collected at each station using a gasoline-powered water pumping system connected to a hose $38 \mathrm{~mm}$ in diameter. The volume was filtered using plankton net with a $55 \mu \mathrm{m}$ mesh size. All samples were preserved with $4 \%$ formalin. 


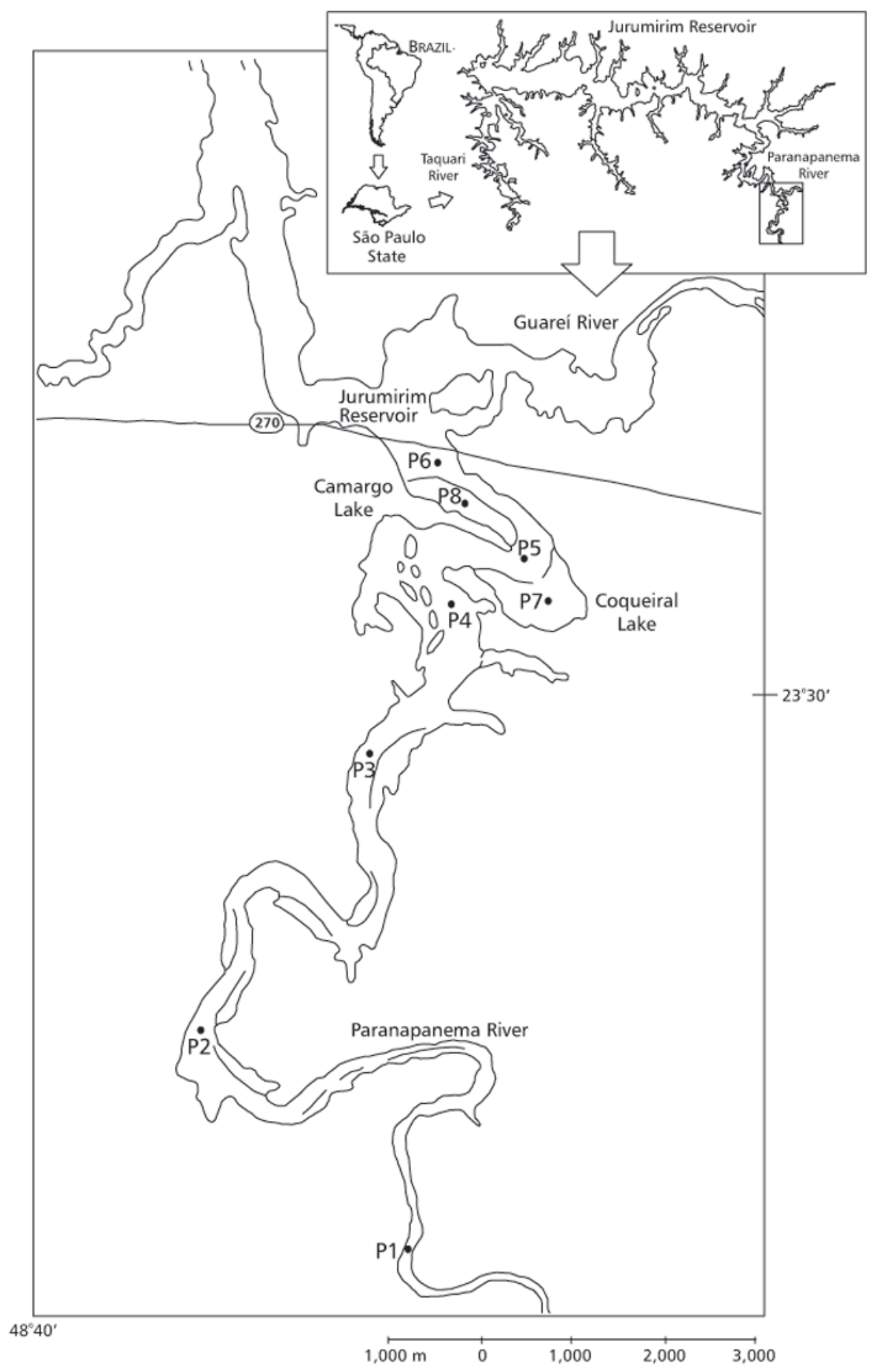

Fig. 1 - Sampling stations in the Paranapanema River mouth into Jurumirim Reservoir (São Paulo State, Brazil). 
Calanoida and Cyclopoida (copepodids and adults) were counted on a stereo microscope (Zeiss, Stemi SV6), using sub-samples with at least 150 individuals or the whole sample when the density of organisms was low. Sub-samples were also used to count nauplii in Sedgwick-Rafter chambers, using an optical microscope (Zeiss, Standard 25). Identification of the species was based on Matsumura-Tundisi (1986), Reid (1985, 1988, 1989), Rocha \& Matsumura-Tundisi (1976), Reid \& PintoCoelho (1994), and Sendacz \& Kubo (1982).

The following parameters were considered: current velocity (current meter ELE at $0.5 \mathrm{~m}$ depth), water temperature (Thermistor Toho Dentan ET3), transparency (Secchi disk), dissolved oxygen (Winkler method, modified by Golterman et al., 1978), pH (pH meter Micronal B-380), conductivity (Conductivity meter Hach 2511 , corrected to $25^{\circ} \mathrm{C}$ ), alkalinity (titration with $0.1 \mathrm{~N} \mathrm{H} 2 \mathrm{SO} 4$, Mackereth et al., 1978), total mitrogen and phosphorus (Valderrama, 1981), total and organic suspended solids (Gravimetry; Teixeira \& Kuthner, 1962), and chlorophyll- $a$ (water filtration through Millipore AP20 membranes, cold acetone 90\% extraction; Golterman et al., 1978).

Statistical analyses were performed to detect significant differences of abiotic factors between sampling sites and periods (ANOVA), and also to show correlations between abiotic factors and copepod population densities (Canonical correlation analysis; Manly, 1994). These analyses were performed considering total copepod density and also the most abundant taxa (up to $10 \%$ of total density, including nauplii and copepodids). For both analyses, the SAS System was used.

\section{RESULTS}

\section{Environmental factors}

From October 1997 to March 1998, monthly precipitation reached the highest values (Fig. 2). From April to August 1998, precipitation values were lower (15\% of the annual precipitation).

Variance analyses revealed temporal $(\mathrm{n}=8$, $\mathrm{p}<0.05)$ and spatial $(\mathrm{n}=4, \mathrm{p}<0.05)$ significant differences for all abiotic factors. Seasonally, two different patterns of environmental factors were observed. Water temperature, current speed, suspended solids (total, organic, and inorganic), and total phosphorus and nitrogen concentrations reached higher values in the rainy season (January and October). Transparency, dissolved oxygen, $\mathrm{pH}$, and conductivity showed higher values during the dry season (April and July) (Table 1).

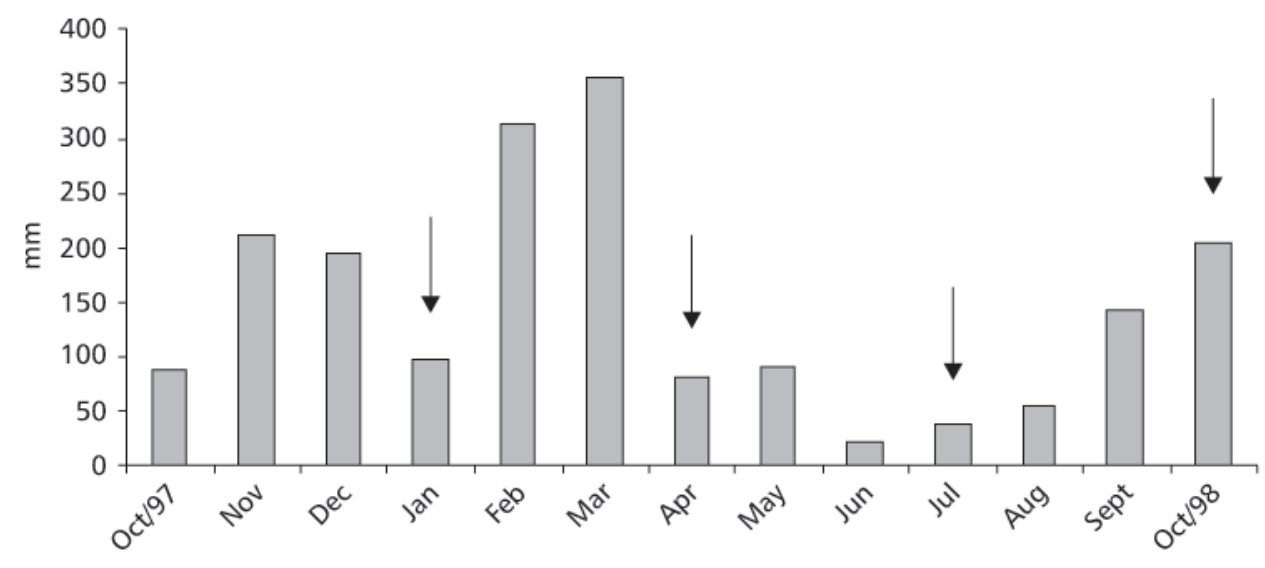

Fig. 2 - Monthly precipitation (mm) in Paranapanema (SP) region, between October 1997 and October 1998 (the arrows indicate the sampling months). 
TABLE 1

Mean values of environmental factors in sampling sites (P1 to P6) of Paranapanema River and lateral lakes (P7 - Coqueiral Lake; P8 - Camargo Lake) in 1998.

\begin{tabular}{|c|c|c|c|c|c|c|c|c|}
\hline & \multicolumn{6}{|c|}{ Lotic stations } & \multicolumn{2}{|c|}{ Lentic stations } \\
\hline & $\mathbf{P 1}$ & $\mathbf{P 2}$ & P3 & P4 & P5 & P6 & P7 & P8 \\
\hline \multicolumn{9}{|l|}{ January } \\
\hline Water transparency $(\mathrm{cm})$ & 18 & 40 & 43 & 21 & 46 & 25 & 51 & 31 \\
\hline Dissolved oxygen $\left(\mathrm{mg} . \mathrm{L}^{-1}\right)$ & 6.96 & 6.69 & 6.51 & 6.31 & 6.61 & 6.52 & 7.13 & 6.51 \\
\hline $\mathrm{pH}$ & 6.3 & 6.2 & 6.1 & 6.0 & 6.3 & 6.4 & 6.6 & 6.4 \\
\hline Water temperature $\left({ }^{\circ} \mathrm{C}\right)$ & 22.3 & 22.1 & 22.6 & 22.7 & 24.5 & 24.9 & 26.4 & 26.0 \\
\hline Chlorophyll- $a$ & 5.80 & 5.18 & 8.17 & 5.74 & 4.80 & 6.68 & 15.92 & 6.93 \\
\hline Alkalinity (mEq. $\mathrm{L}^{-1}$ ) & 0.351 & 0.364 & 0.343 & 0.328 & 0.366 & 0.373 & 0.417 & 0.390 \\
\hline Conductivity $\left(\mu \mathrm{S} . \mathrm{cm}^{-1}\right)$ & 53 & 50 & 50 & 52 & 54 & 52 & 55 & 55 \\
\hline Organic suspended solids $\left(\mathrm{mg} . \mathrm{L}^{-1}\right)$ & 0.86 & 0.66 & 0.55 & 0.42 & 0.73 & 0.82 & 0.54 & 0.55 \\
\hline Inorganic suspended solids $\left(\mathrm{mg} \cdot \mathrm{L}^{-1}\right)$ & 5.56 & 4.29 & 3.18 & 3.16 & 2.66 & 3.56 & 0.81 & 1.40 \\
\hline Total nitrogen $\left(\mu \mathrm{g} . \mathrm{L}^{-1}\right)$ & 1,188 & 937 & 1,034 & 934 & 496 & 332 & 719 & 580 \\
\hline Total phosphorus $\left(\mu \mathrm{g} \cdot \mathrm{L}^{-1}\right)$ & 44 & 29 & 28 & 28 & 28 & 22 & 14 & 15 \\
\hline \multicolumn{9}{|l|}{ April } \\
\hline Water transparency $(\mathrm{cm})$ & 50 & 50 & 58 & 59 & 64 & 69 & 63 & 75 \\
\hline Dissolved oxygen (mg. $\left.\mathrm{L}^{-1}\right)$ & 7.22 & 7.17 & 7.21 & 7.26 & 7.25 & 7.25 & 6.33 & 6.73 \\
\hline $\mathrm{pH}$ & 6.7 & 6.9 & 6.9 & 7.1 & 7.2 & 7.2 & 7.1 & 7.1 \\
\hline Water temperature $\left({ }^{\circ} \mathrm{C}\right)$ & 16.3 & 16.5 & 18.7 & 17.9 & 18.7 & 18.3 & 21.4 & 20.2 \\
\hline Chlorophyll- $a$ & 3.37 & 4.05 & 2.81 & 4.37 & 3.81 & 4.93 & 4.74 & 5.49 \\
\hline Alkalinity (mEq. $\left.\mathrm{L}^{-1}\right)$ & 0.466 & 0.459 & 0.460 & 0.510 & 0.512 & 0.524 & 0.479 & 0.505 \\
\hline Conductivity $\left(\mu \mathrm{S} . \mathrm{cm}^{-1}\right)$ & 64 & 64 & 66 & 62 & 62 & 64 & 59 & 62 \\
\hline Organic suspended solids (mg. $\mathrm{L}^{-1}$ ) & 0.44 & 0.33 & 0.25 & 0.21 & 0.24 & 0.27 & 0.23 & 0.25 \\
\hline Inorganic suspended solids $\left(\mathrm{mg} \cdot \mathrm{L}^{-1}\right)$ & 2.23 & 1.98 & 1.18 & 1.15 & 1.28 & 1.30 & 0.98 & 1.01 \\
\hline Total nitrogen $\left(\mu \mathrm{g} . \mathrm{L}^{-1}\right)$ & 281 & 311 & 165 & 166 & 94 & 43 & 86 & 135 \\
\hline Total phosphorus $\left(\mu \mathrm{g} . \mathrm{L}^{-1}\right)$ & 15 & 14 & 12 & 9 & 8 & 10 & 8 & 7 \\
\hline \multicolumn{9}{|l|}{ July } \\
\hline Water transparency $(\mathrm{cm})$ & 84 & 73 & 89 & 85 & 83 & 73 & 85 & 97 \\
\hline Dissolved oxygen $\left(\mathrm{mg} . \mathrm{L}^{-1}\right)$ & 9.12 & 9.00 & 9.11 & 8.75 & 8.80 & 8.90 & 8.39 & 8.77 \\
\hline $\mathrm{pH}$ & 7.0 & 7.0 & 7.0 & 7.0 & 7.0 & 7.0 & 7.0 & 7.0 \\
\hline Water temperature $\left({ }^{\circ} \mathrm{C}\right)$ & 14.7 & 15.0 & 14.7 & 15.1 & 15.5 & 14.9 & 19.0 & 17.0 \\
\hline Chlorophyll- $a$ & 3.93 & 3.87 & 2.81 & 4.43 & 4.49 & 5.05 & 7.80 & 5.99 \\
\hline Alkalinity $\left(\mathrm{mEq} \cdot \mathrm{L}^{-1}\right)$ & 0.417 & 0.408 & 0.412 & 0.407 & 0.406 & 0.418 & 0.407 & 0.418 \\
\hline Conductivity $\left(\mu \mathrm{S} . \mathrm{cm}^{-1}\right)$ & 74 & 73 & 72 & 73 & 74 & 72 & 67 & 68 \\
\hline Organic suspended solids $\left(\mathrm{mg} . \mathrm{L}^{-1}\right)$ & 0.41 & 0.48 & 0.39 & 0.34 & 0.38 & 0.43 & 0.30 & 0.21 \\
\hline Inorganic suspended solids $\left(\mathrm{mg} \cdot \mathrm{L}^{-1}\right)$ & 0.72 & 0.92 & 0.19 & 0.18 & 0.33 & 0.42 & 0.06 & 0.00 \\
\hline Total nitrogen $\left(\mu \mathrm{g} . \mathrm{L}^{-1}\right)$ & 140 & 233 & 353 & 352 & 352 & 343 & 341 & 214 \\
\hline Total phosphorus $\left(\mu \mathrm{g} . \mathrm{L}^{-1}\right)$ & 13 & 16 & 9 & 9 & 14 & 16 & 16 & 12 \\
\hline
\end{tabular}


TABLE 1 (Continued.)

\begin{tabular}{|c|c|c|c|c|c|c|c|c|}
\hline & \multicolumn{6}{|c|}{ Lotic stations } & \multicolumn{2}{|c|}{ Lentic stations } \\
\hline & $\mathbf{P 1}$ & $\mathbf{P 2}$ & P3 & $\mathbf{P 4}$ & P5 & P6 & P7 & P8 \\
\hline \multicolumn{9}{|l|}{ October } \\
\hline Water transparency $(\mathrm{cm})$ & 38 & 39 & 40 & 42 & 37 & 49 & 33 & 43 \\
\hline Dissolved oxygen $\left(\mathrm{mg} . \mathrm{L}^{-1}\right)$ & 6.99 & 7.07 & 6.84 & 7.02 & 6.97 & 6.92 & 7.47 & 7.17 \\
\hline $\mathrm{pH}$ & 7.0 & 7.0 & 6.9 & 6.9 & 6.9 & 6.9 & 6.9 & 7.0 \\
\hline Water temperature $\left({ }^{\circ} \mathrm{C}\right)$ & 20.4 & 20.6 & 20.7 & 20.1 & 20.2 & 20.1 & 21.3 & 21.7 \\
\hline Chlorophyll- $a$ & 17.41 & 17.04 & 16.86 & 14.45 & 9.36 & 12.29 & 14.05 & 12.86 \\
\hline Alkalinity (mEq. $\mathrm{L}^{-1}$ ) & 0.336 & 0.337 & 0.341 & 0.321 & 0.321 & 0.339 & 0.316 & 0.360 \\
\hline Conductivity $\left(\mu \mathrm{S} . \mathrm{cm}^{-1}\right)$ & 54 & 52 & 53 & 50 & 49 & 57 & 50 & 58 \\
\hline Organic suspended solids (mg. $\mathrm{L}^{-1}$ ) & 0.82 & 0.65 & 0.49 & 0.55 & 0.56 & 0.65 & 0.29 & 0.35 \\
\hline Inorganic suspended solids $\left(\mathrm{mg} . \mathrm{L}^{-1}\right)$ & 4.55 & 4.44 & 3.90 & 2.47 & 3.11 & 2.69 & 1.32 & 1.00 \\
\hline Total nitrogen $\left(\mu \mathrm{g} . \mathrm{L}^{-1}\right)$ & 319 & 325 & 224 & 224 & 210 & 187 & 188 & 183 \\
\hline Total phosphorus $\left(\mu \mathrm{g} . \mathrm{L}^{-1}\right)$ & 48 & 48 & 44 & 57 & 33 & 40 & 37 & 46 \\
\hline
\end{tabular}

Water temperature and transparency increased towards upstream from station P1 to P6. On the other hand, current velocity, dissolved oxygen, suspended solids, nutrients, and chlorophyll $a$ decreased in the opposite direction, reaching minimum values near the reservoir. Current velocity (Fig. 3) and suspended solids (Fig. 4) decreased considerably downstream. No longitudinal pattern for alkalinity, $\mathrm{pH}$, and conductivity was recorded.

Inorganic fraction predominated for suspended solids in river and lakes, except for July, when organic fraction attained $83 \%$ and $100 \%$ of suspended solids in Coqueiral and Camargo lakes, respectively.

Lateral lakes presented singular features. Water temperature, transparency, and chlorophyll- $a$ were higher, whereas suspended solids, dissolved oxygen, and nitrogen and phosphorus concentrations were lower than the values found in the river channel.

\section{COPEPODA}

The copepod assemblage in the Paranapanema River and lateral lakes was composed by 9 taxa. The calanoid Notodiaptomus conifer (Wright) and the cyclopoids Paracyclops (Claus) and Thermocyclops decipiens (Fischer), in addition to $T$. minutus (Lowndes), were common to both systems, i.e., river and lakes. Only in the river, the calanoids Argyrodiaptomus furcatus (Sars) and Notodiaptomus iheringi (Wright), and the cyclopoids Eucyclops (Claus) and Mesocyclops longisetus (Thiébaud) were found. Conversely, the cyclopoid Microcyclops (Claus) was only found in the lateral lakes. Harpacticoids were recorded in both environments.

Argyrodiaptomus furcatus and $N$. iheringi, observed only in the river, were found in the rainy season (Table 2). Mesocyclops longisetus and Eucyclops sp. were found in higher densities in the rainy season. However, Eucyclops sp. occurred in very low density $\left(1\right.$ ind. $\left.\mathrm{m}^{-3}\right)$ in July. Among the species common to both systems, higher densities of $N$. conifer were detected in the river channel during the rainy season.

High densities of copepods in the river channel were observed in October $\left(9,913\right.$ ind. $\left.\mathrm{m}^{-3}\right)$, and low in July (436 ind $\mathrm{m}^{-3}$ ), while in lateral lakes they occurred in April $\left(151,074\right.$ ind. $\left.{ }^{-3}\right)$ and July $(44,788$ ind. $\left.\mathrm{m}^{-3}\right)$, respectively. 

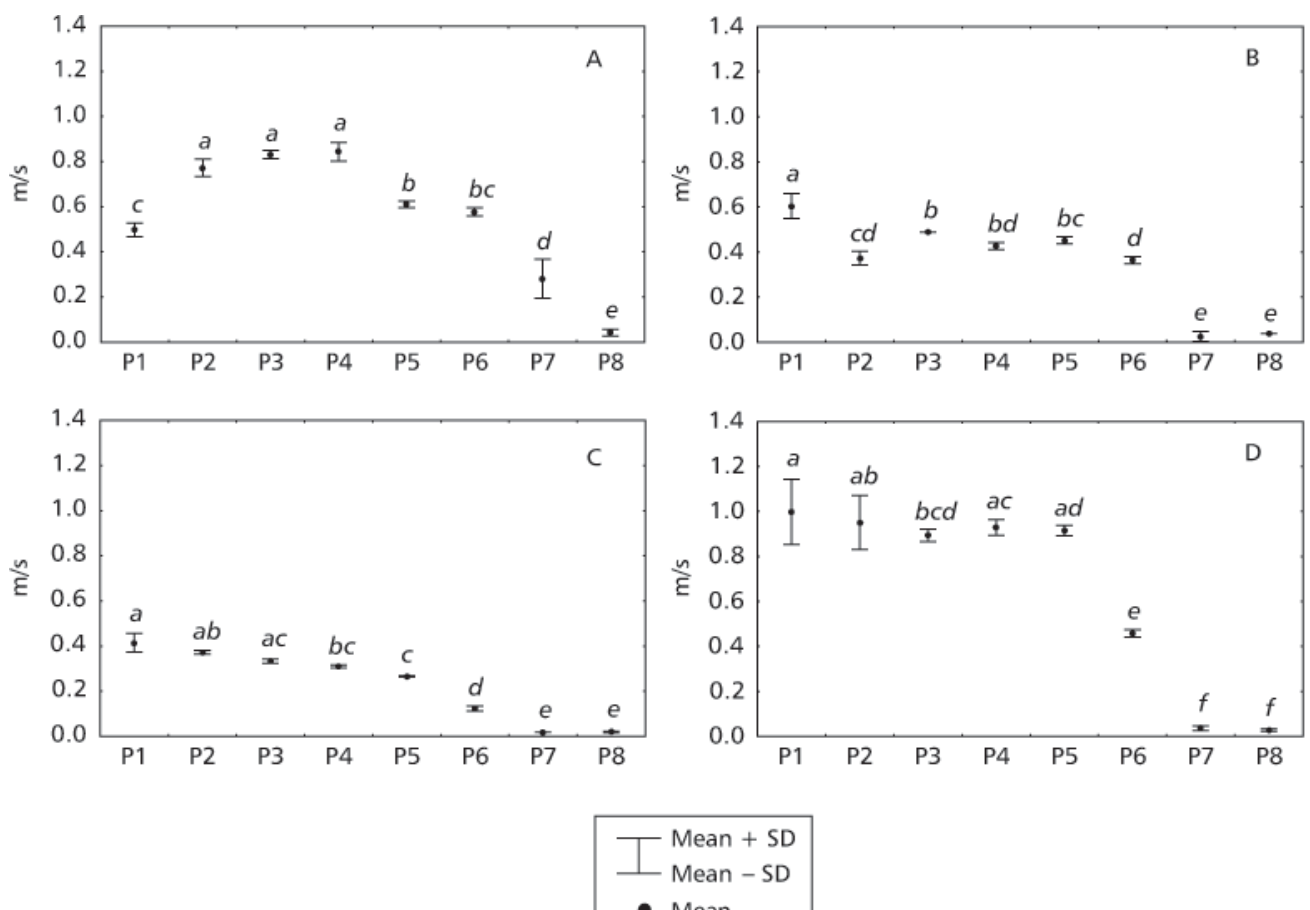

Fig. 3 - Current velocity in January (A), April (B), July (C), and October (D) of 1998, in Paranapanema River (P1 to P6) and in lateral lakes (P7 - Coqueiral Lake; P8 - Camargo Lake). Statistically significant differences are represented by different letters $(\mathrm{p}<0.05)$.
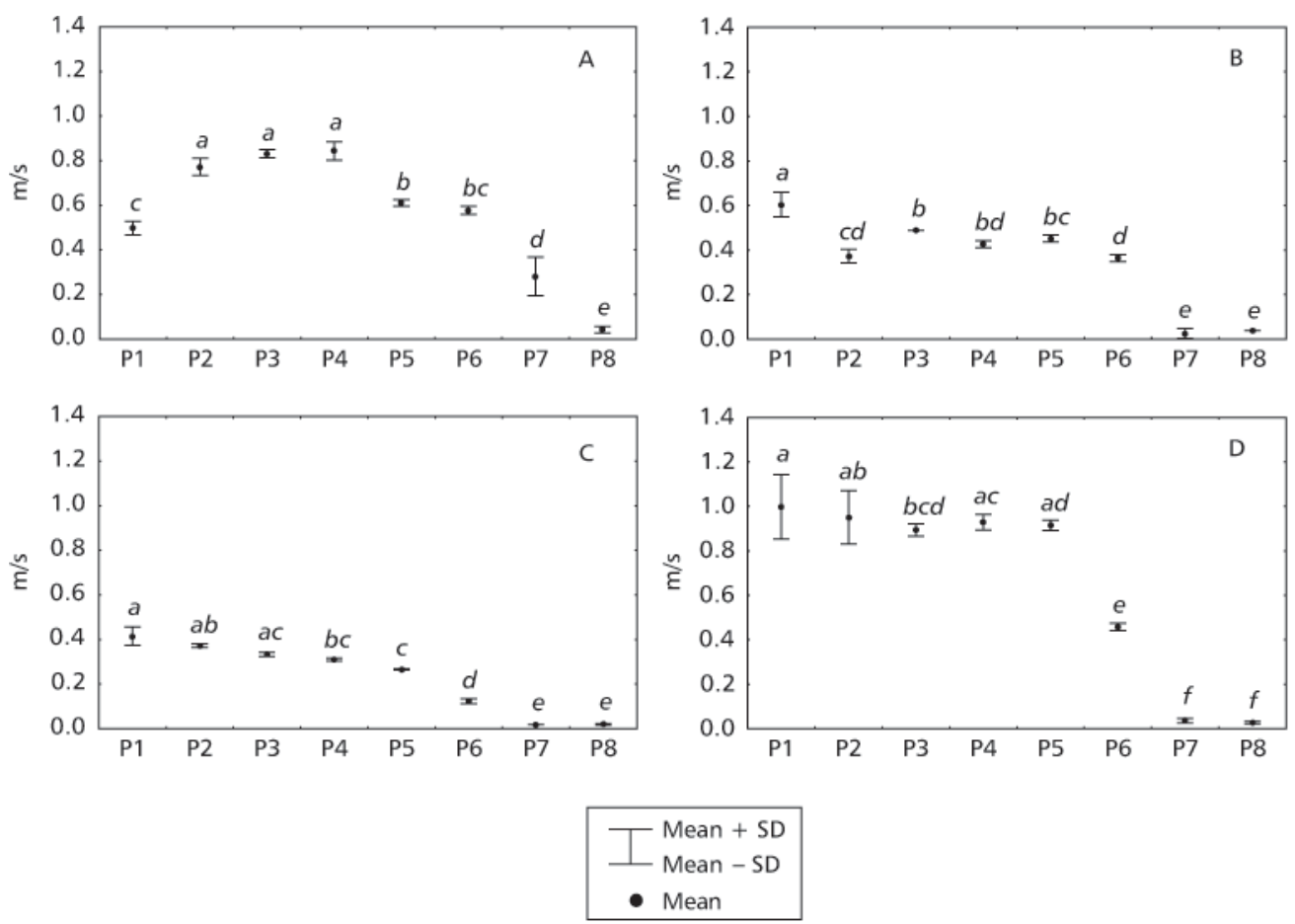

Fig. 4 - Suspended solids in January (A), April (B), July (C), and October (D) of 1998, in Paranapanema River (P1 to P6) and in lateral lakes (P7 - Coqueiral Lake; P8 - Camargo Lake). Statistically significant differences are represented by different letters $(\mathrm{p}<0.05)$. 
TABLE 2

Copepods abundance (ind. $\mathrm{m}^{-3}$ ) in Paranapanema River (P1 a P6) and lateral lakes (P7 - Coqueiral Lake; P8 - Camargo Lake) in 1998.

\begin{tabular}{|c|c|c|c|c|c|c|c|c|}
\hline & \multicolumn{6}{|c|}{ Lotic stations } & \multicolumn{2}{|c|}{ Lentic stations } \\
\hline & P1 & $\mathbf{P 2}$ & P3 & P4 & P5 & P6 & P7 & P8 \\
\hline \multicolumn{9}{|l|}{ January } \\
\hline Eucyclops sp. & 3 & 0 & 9 & 3 & 94 & 4 & 0 & 0 \\
\hline Mesocyclops longisetus & 0 & 0 & 0 & 3 & 98 & 0 & 0 & 0 \\
\hline Microcyclops sp. & 0 & 0 & 0 & 0 & 0 & 0 & 8 & 0 \\
\hline Notodiaptomus conifer & 9 & 0 & 3 & 46 & 94 & 4 & 0 & 0 \\
\hline Notodiaptomus iheringi & 0 & 0 & 0 & 6 & 3 & 4 & 0 & 0 \\
\hline Paracyclops sp. & 0 & 0 & 0 & 0 & 3 & 0 & 16 & 0 \\
\hline Thermocyclops minutus & 4 & 7 & 11 & 40 & 0 & 18 & 110 & 355 \\
\hline Thermocyclops decipiens & 6 & 4 & 9 & 10 & 94 & 21 & 546 & 539 \\
\hline \multicolumn{9}{|l|}{ April } \\
\hline Eucyclops sp. & 0 & 0 & 0 & 4 & 0 & 3 & 0 & 0 \\
\hline Mesocyclops longisetus & 0 & 1 & 0 & 0 & 4 & 0 & 0 & 0 \\
\hline Microcyclops sp. & 0 & 0 & 0 & 0 & 0 & 0 & 237 & 113 \\
\hline Notodiaptomus conifer & 0 & 0 & 2 & 0 & 9 & 4 & 60 & 0 \\
\hline Paracyclops sp. & 148 & 1 & 0 & 1 & 0 & 0 & 116 & 87 \\
\hline Thermocyclops decipiens & 8 & 2 & 8 & 3 & 5 & 12 & 1,590 & 398 \\
\hline Thermocyclops minutus & 3 & 6 & 5 & 2 & 0 & 13 & 373 & 155 \\
\hline \multicolumn{9}{|l|}{ July } \\
\hline Eucyclops sp. & 0 & 0 & 0 & 0 & 0 & 1 & 0 & 0 \\
\hline Paracyclops sp. & 0 & 1 & 0 & 0 & 1 & 0 & 0 & 0 \\
\hline Thermocyclops decipiens & 3 & 2 & 1 & 2 & 1 & 6 & 2,167 & 224 \\
\hline Thermocyclops minutus & 0 & 0 & 3 & 0 & 4 & 4 & 1,511 & 326 \\
\hline \multicolumn{9}{|l|}{ October } \\
\hline Argyrodiaptomus furcatus & 0 & 0 & 0 & 0 & 5 & 0 & 0 & 0 \\
\hline Ergasilus sp. & 0 & 6 & 0 & 0 & 0 & 0 & 0 & 74 \\
\hline Eucyclops sp. & 0 & 0 & 0 & 6 & 5 & 4 & 0 & 0 \\
\hline Mesocyclops longisetus & 4 & 11 & 26 & 3 & 33 & 4 & 0 & 0 \\
\hline Notodiaptomus conifer & 0 & 0 & 6 & 8 & 0 & 0 & 0 & 0 \\
\hline Paracyclops sp. & 9 & 25 & 14 & 6 & 0 & 4 & 0 & 0 \\
\hline Thermocyclops decipiens & 15 & 24 & 20 & 25 & 34 & 39 & 1,081 & 545 \\
\hline Thermocyclops minutus & 79 & 44 & 44 & 56 & 59 & 46 & 722 & 455 \\
\hline
\end{tabular}


A copepod density decrease was observed in the river toward the reservoir (specially between P1 and P5 stations). However, in July and October an increase was observed in P6, located in front of Camargo Lake. In the lentic habitats, copepod density was always higher than that in the river system (Fig. 5A, C, E, and G).

Cyclopoids were usually more abundant in all stations and throughout the year $(<50 \%)$. Cyclopoids and harpacticoids were more abundant in the river compared to lakes, in which cyclopoids reached more than $90 \%$ of the total density in January and October (Fig. 5B and $\mathrm{H}$ ). In the river, harpacticoids predominated only in April in upstream stations, reaching $78 \%$ of the total density in P1 (Fig. 5D). In lateral lakes, harpacticoid density was never more than $0.2 \%$. Calanoid density was always lower than $22 \%$ of Copepoda total density in the river, and reached a maximum of $36 \%$ in April, in Camargo Lake (Fig. 5D).

Calanoid and cyclopoid nauplii and copepodids, and harpacticoids were the most abundant copepods, while adults always represented lower densities (Table 2). Concerning calanoids, nauplii and copepodids were scarcely represented in the river channel. In the lakes, the densities were always higher than in the river (Fig. 6). Longitudinal increase in nauplii density occurred in January, July, and October (Fig. 6A, B and D). For copepodids, density increased only in April (Fig. 6B). In July, copepodid density in the river was near to zero (Fig. 6C). In January and October, no significant longitudinal variations were found (Fig. $6 \mathrm{~A}$ and $\mathrm{D})$.

A longitudinal decrease in cyclopoid nauplii and copepodid density occurred from P1 to P4 stations. However, an increase was recorded near lateral lakes, specially in front of Camargo Lake (P6) (Fig. 7). Higher densities were observed inside the lakes.

In the river channel, harpacticoid density decreased from P1 to P6 stations. In lateral lakes, nauplii were absent while copepodids and adults occurred only in January (Coqueiral Lake) and in July (Camargo Lake) (Fig. 8).

\section{Correlation between species and environmental variables}

The correlation coefficient corresponding to the first three pairs of canonical variables was significant $(\mathrm{p}<0.05)$. Nauplii and adult harpacticoids were positively correlated with chlorophyll- $a$, total phosphorus, suspended solids (total and organic), temperature, and current velocity. However, they were negatively correlated with alkalinity, conductivity, dissolved oxygen, and water transparency $(R a=0.974$; $\mathrm{p}<0.0001$ ) (Table 3). The second pair of canonical variables $(R a=0.957 ; \mathrm{p}<0.0001)$ showed a negative correlation of copepoda (total) with current velocity and suspended solids. Other correlations of these variables were also obtained, being positive in relation to harpacticoid nauplii, copepodids, and adults, and negative to calanoid and cyclopoid nauplii and copepodids (Table 3 ). The third pair of canonical variables $(R a=0.8285 ; \mathrm{p}<0.0001)$ showed a positive correlation of Copepoda (total), calanoid and cyclopoid nauplii and copepodids with water temperature, and negative with dissolved oxygen (Table 3).

\section{DISCUSSION}

Rivers are systems in which water movement is horizontal. In these systems, water, nutrients, sediments, and organisms move according to the water speed. This flow is permanent and is a controlling factor in the distribution and abundance of organisms (Neiff, 1996). Since rivers present a strong relationship with lateral lakes and terrestrial habitats, to determine if the zooplankton community shows a similarity with that in the lentic environments, laterally associated with the river system, is important.

Among the species collected, four of nine were sampled only in the Paranapanema River, while just one was limited to the lakes. For these species, distribution is probably related to the season, since some of them were observed in higher densities in the rainy season while others were found exclusively in this period. The high biotic exchange between these different systems, when the water level is high, can explain this observation. According to Paggi \& Jose de Paggi (1990), the annual fluctuations of water level show a positive relationship with specific richness, as a consequence of the added population coming from lentic water bodies to the lotic environment.

Concerning the nonoccurrence of adult instars of these species in the lakes, Martins (2000) observed high densities of Notodiaptomus spp. in the littoral habitats of Camargo Lake. 

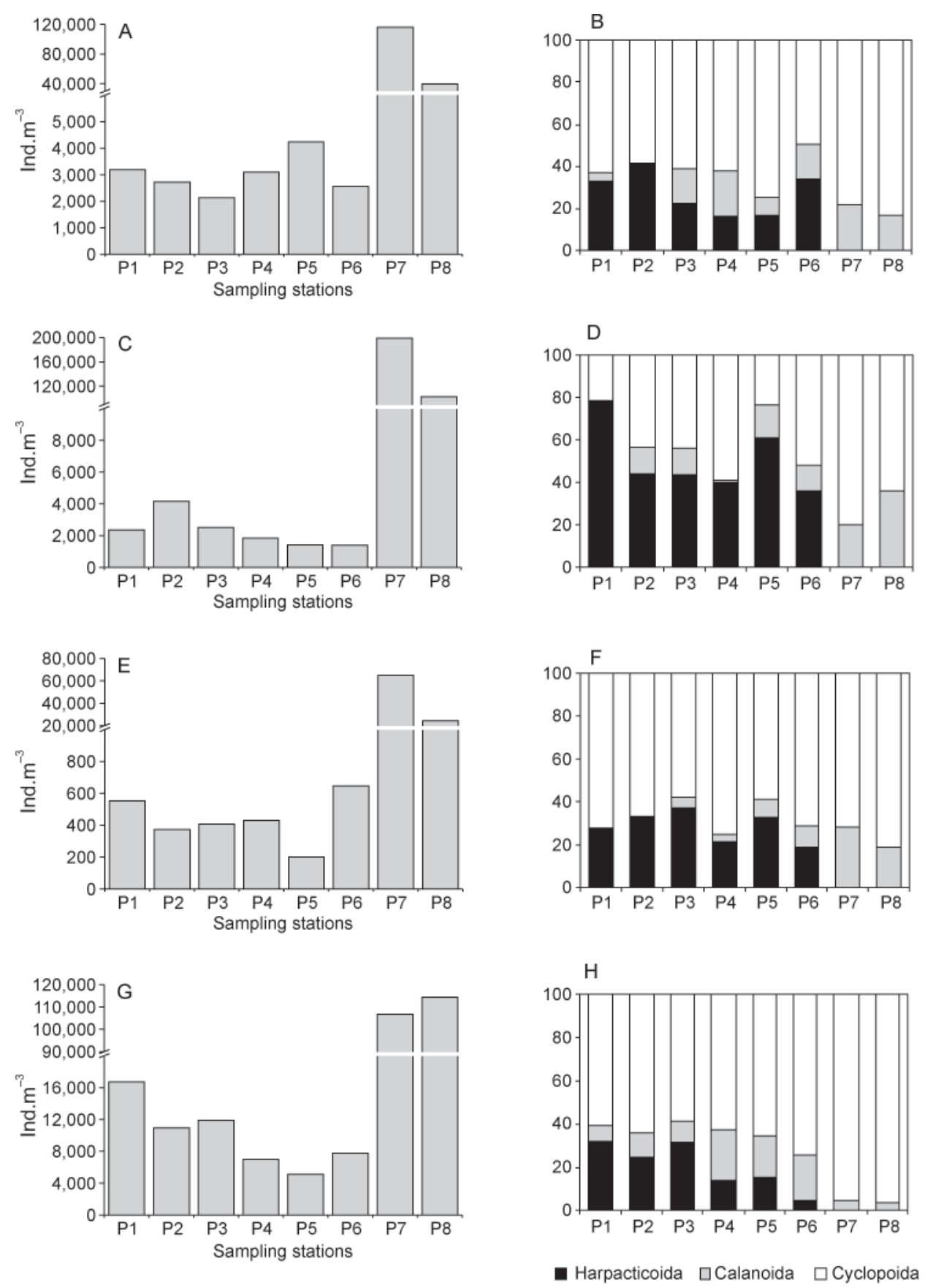

Fig. 5 - Total of Copepods (ind. $\mathrm{m}^{-3}$ ) and relative abundance (\%) of Calanoida, Cyclopoida, and Harpacticoida in Paranapanema River (P1 to P6) and in lateral lakes (P7 - Coqueiral Lake; P8 - Camargo Lake), in January (A, B), April (C, D), July (E, F), and October $(\mathrm{G}, \mathrm{H}) 1998$. 

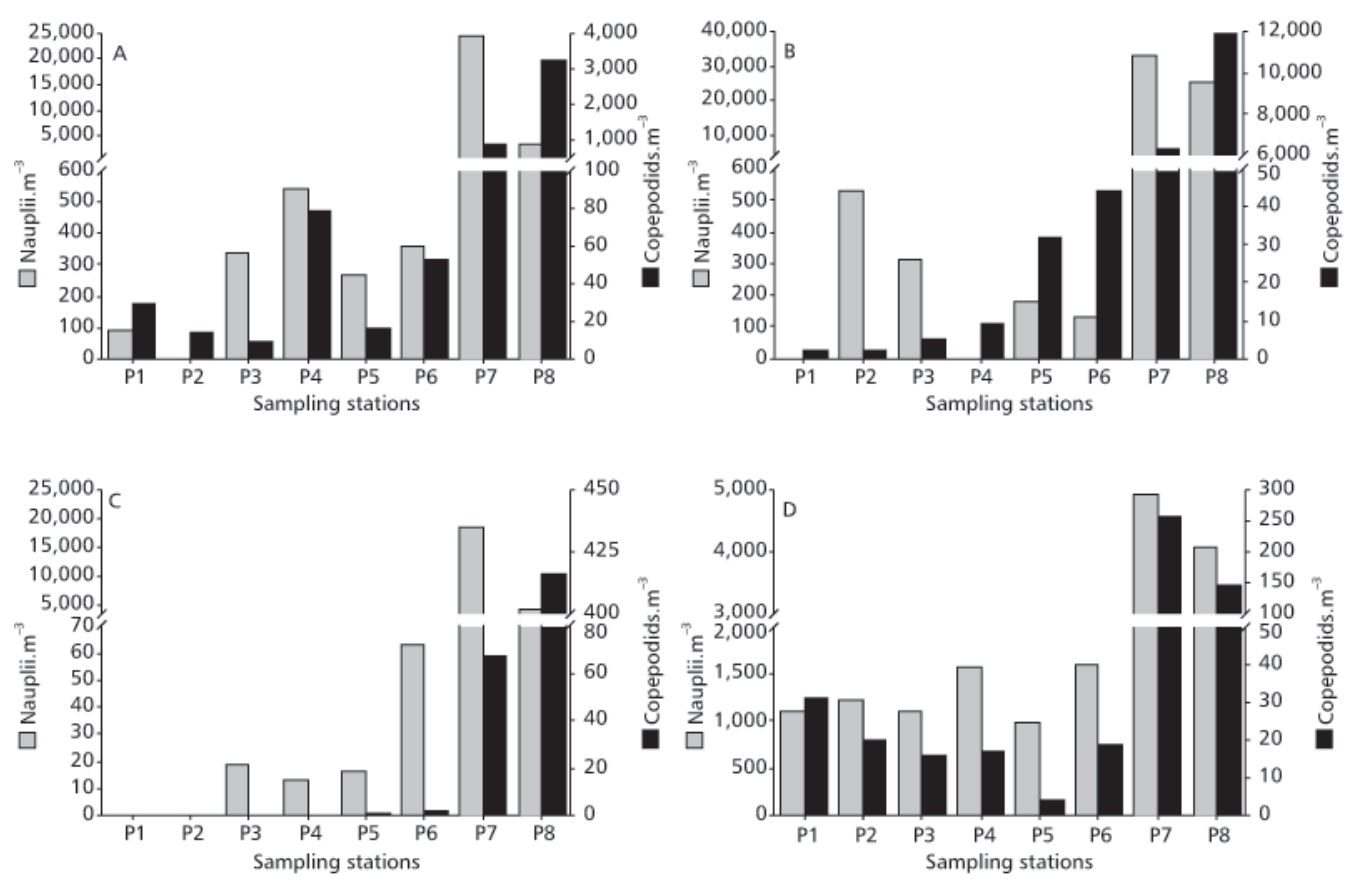

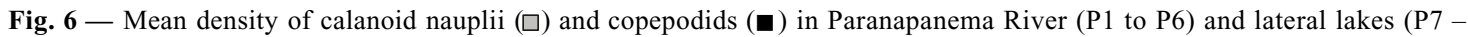
Coqueiral Lake and P8 - Camargo Lake), in January (A), April (B), July (C), and October (D) 1998.
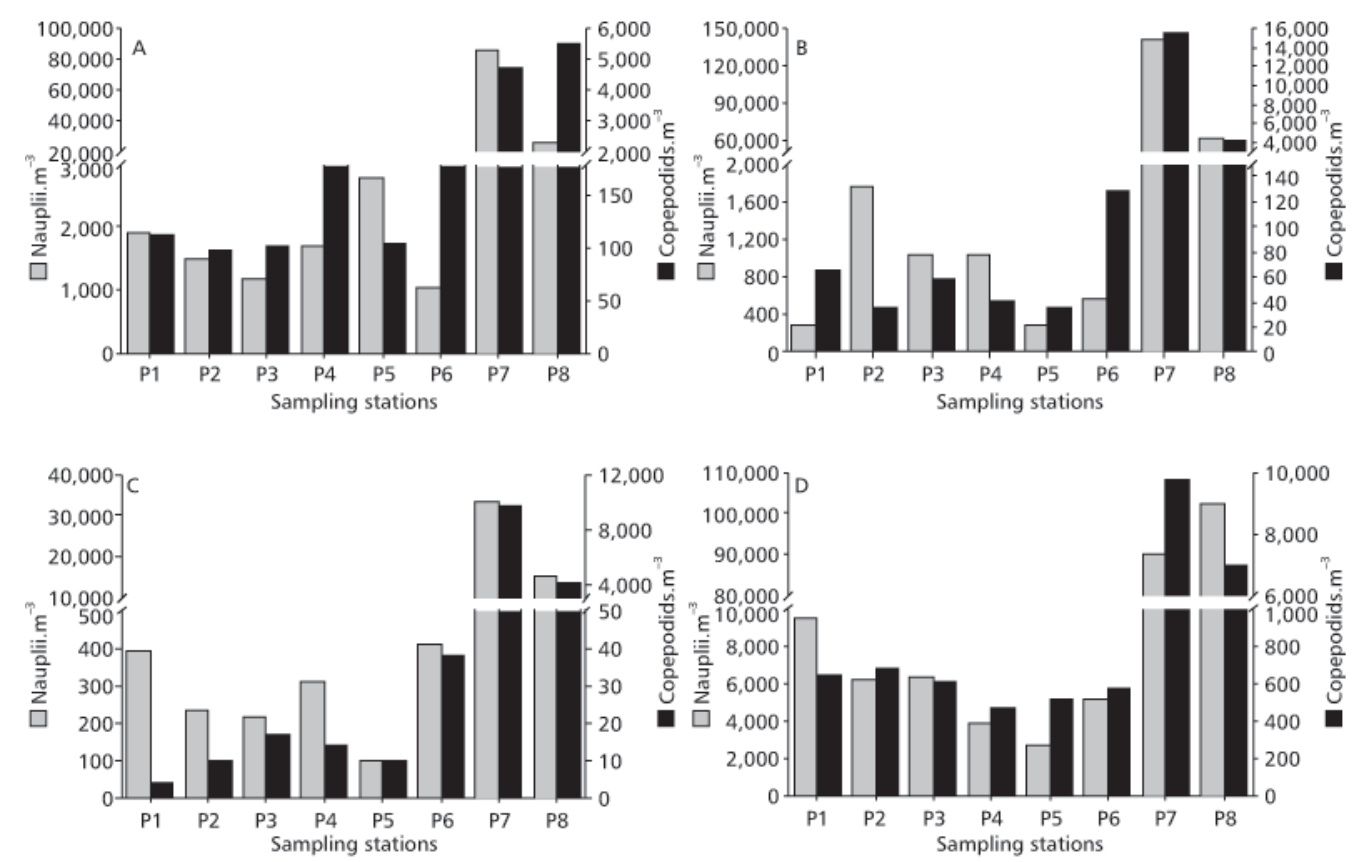

Fig. 7 - Mean density of cyclopoid nauplii $(\square)$ and copepodids (ロ) in Paranapanema River (P1 to P6) and lateral lakes (P7 Coqueiral Lake and P8 - Camargo Lake), in January (A), April (B), July (C), and October (D) 1998. 

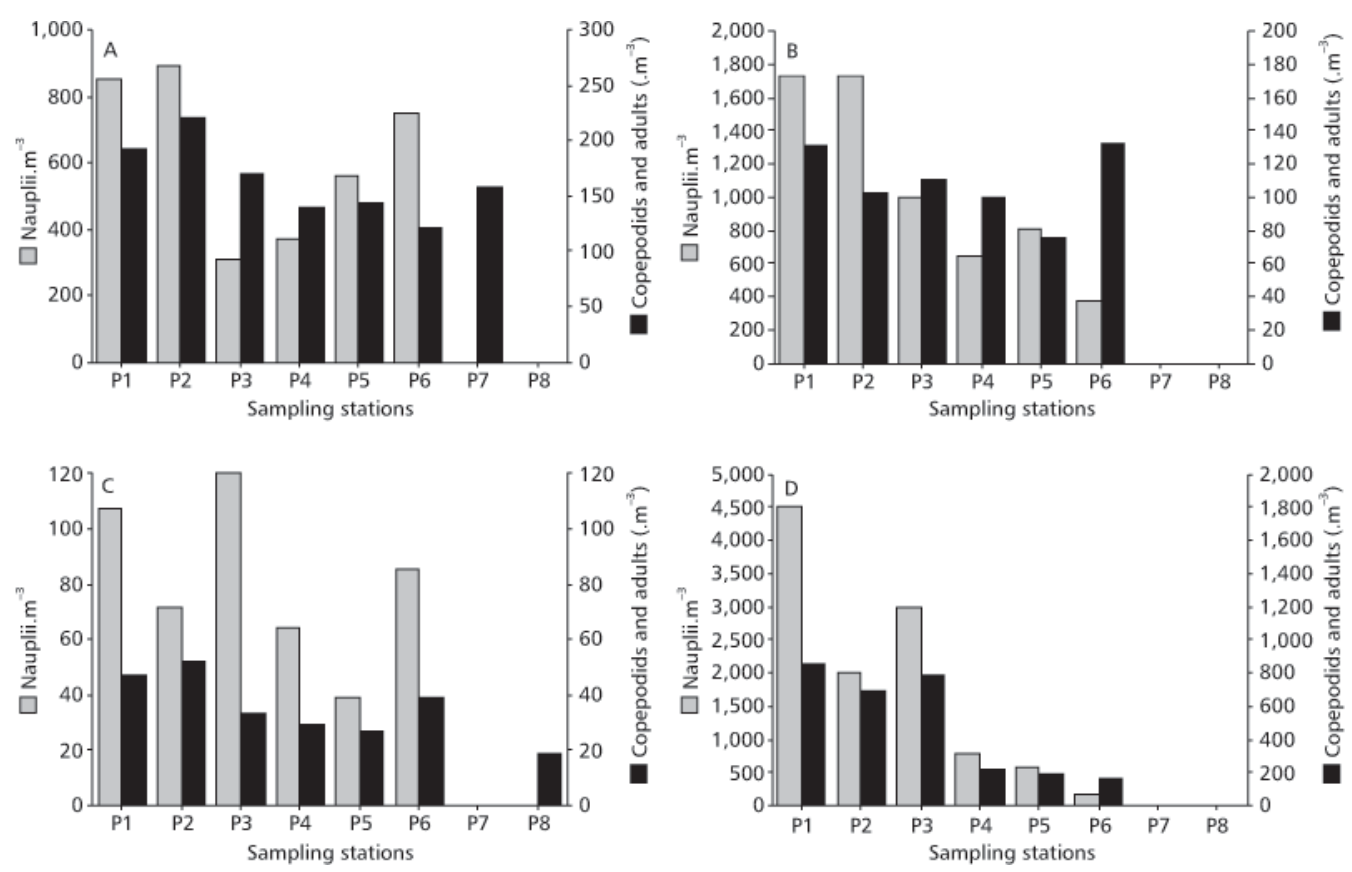

Fig. 8 - Mean density of harpacticoid nauplii ( $\square$ ) and copepodids and adults ( $\square$ ) in Paranapanema River (P1 to P6) and lateral lakes (P7 - Coqueiral Lake and P8 - Camargo Lake), in January (A), April (B), July (C), and October (D) 1998.

Copepod richness in the river (6 taxa) and in the lakes ( 5 taxa) was similar due to the influence of high precipitations, rising of water level, and consequent water exchange between river and lakes and, thus, of the number of taxa. Lansac-Tôha et al. (1997) obtained similar patterns in lotic, semilotic, and lentic environments in the Upper Paraná floodplain. There are permanent interchanges between microcrustacean fauna of lakes, channels, and rivers in the limnetic and littoral zones, due to interconnections between systems and to the water level variation pattern.

Though the number of cyclopoid species is relatively low (6), a similar observation was obtained by Sendacz $(1993,2001)$ in the Upper Paraná River and in 7 lateral lakes (4 and 2 species, respectively) and Velho et al. (2001) in the Corumbá River and Reservoir (3 species). On the other hand, Paggi \& Jose de Paggi (1990) found
25 species in lentic and lotic environments in the middle Paraná River, of which 9 species were common to rivers and ponds.

In this study, Calanoida was scarcely represented (3 species) compared to other studies in the Upper Paraná River and its lateral lakes (7 species; Sendacz, 1993, 2001), the Orinoco River and its floodplain lakes (13 species; Dussart, 1984), and in the southern Pantanal (4 species, Reid \& Moreno, 1990). In the other hand, Velho et al. (2001) found only one calanoid (Notodiaptomus iheringi) in 21 sampling stations along the Corumbá Reservoir, including the river (upstream and downstream from the dam), tributaries, and lateral arms. In this study, Notodiaptomus iheringi reached small densities although it was frequent and, attained high densities in the lacustrine zone of Jurumirim Reservoir (Nogueira \& Panarelli, 1997; Panarelli et al., 2001; Nogueira, 2001). 
TABLE 3

Correlation between copepod abundance and canonical variables $\left(V_{1}, V_{2}\right.$ and $\left.V_{3}\right)$ and correlation between environmental factors and canonical variables $\left(W_{1}, W_{2}\right.$ and $\left.W_{3}\right)$.

\begin{tabular}{|c|c|c|c|}
\hline Abiotic variables & $\begin{array}{c}\text { Canonical } \\
\text { variable }\end{array}$ & Biotic variables & $\begin{array}{c}\text { Canonical } \\
\text { variable }\end{array}$ \\
\hline & $V_{1}$ & & $W_{1}$ \\
\hline Alkalinity & -0.751 & Harpacticoid nauplii & 0.525 \\
\hline Conductivity & -0.789 & Harpacticoid (copepodids and adults) & 0.748 \\
\hline Dissolved oxygen & -0.528 & & \\
\hline Transparancy & -0.696 & & \\
\hline Clorophyll- $a$ & 0.814 & & \\
\hline Total phosphorus & 0.877 & & \\
\hline Suspended solids & 0.756 & & \\
\hline Organic suspended solids & 0.554 & & \\
\hline Water temperature & 0.529 & & \\
\hline \multirow[t]{2}{*}{ Current velocity } & 0.644 & & \\
\hline & $V_{2}$ & & $W_{2}$ \\
\hline Current velocity & -0.622 & Copepod (total) & 0.658 \\
\hline \multirow[t]{4}{*}{ Suspended solids } & -0.425 & Cyclopoid copepodid & 0.704 \\
\hline & & Cyclopoid nauplii & 0.692 \\
\hline & & Calanoid nauplii & 0.433 \\
\hline & $V_{3}$ & & $W_{3}$ \\
\hline Dissolved oxygen & 0.686 & Copepod (total) & -0.537 \\
\hline \multirow[t]{4}{*}{ Water temperature } & -0.423 & Calanoid copepodids & -0.695 \\
\hline & & Cyclopoid copepodids & -0.425 \\
\hline & & Calanoid nauplii & -0.539 \\
\hline & & Cyclopoid nauplii & -0.491 \\
\hline
\end{tabular}

Cyclopoids were represented by Mesocyclops and Thermocyclops, the latter genus being the most abundant. Thermocyclops was represented by two species, T. minutus and T. decipiens. These species are the most abundant cyclopoids in Jurumirim Reservoir (Nogueira, 2001). T. decipiens presents a dominance in the crustacean zooplankton from mesotrophic to eutrophic reservoirs, while $T$. minutus, though present in large populations in some eutrophic systems, tends to be more numerous in oligotrophic to mesotrophic reservoirs (Reid, 1989). This pattern was not observed in the Paranapanema River mouth since both species occurred in similar densities.
The average density of copepods in Paranapanema River was high (3,911 ind. $\left.\mathrm{m}^{-3}\right)$. Similar data were reported by Lansac-Tôha et al. (1997) for lotic environments of the Upper Paraná River floodplain (1,500-2,000 ind. $\mathrm{m}^{-3}$ ), and by Vasquez \& Rey (1989) in the Orinoco River and its delta (Venezuela) $\left(1,500-3,400\right.$ ind. $\left.\mathrm{m}^{-3}\right)$. High abundance was due to high densities of young instars (nauplii and copepodids). Similar observations were reported by Saunders \& Lewis (1988) for the Caura River (Venezuela), by Sendacz (1993) and LansacTôha et al. (1997) for the Upper Paraná River; and by Carvalho (1983) and Hardy et al. (1984) for the Amazon River Floodplain. 
Sendacz (1993) pointed out that in the Upper Paraná systems, especially in Lake Jota, copepodids reached higher densities than did nauplii. Copepod ontogeny involves great modifications in body size, behavior, and feeding; thus, suitable conditions for one instar of the life cycle of a species are frequently inappropriate for another instar. Hardy (1980) and Carvalho (1983) found that nauplii correspond to from $60 \%$ to $98 \%$ of the total zooplankton in Amazonian lakes. Carvalho (1983) observed that in the Grande Lake (AM), except for T. minutus, adult instars always had densities below $1 \%$ of total copepod abundance.

In the Caura River (Venezuela), Saunders \& Lewis (1988) found cyclopoid nauplii accounting for $85 \%$ of the copepods. According to the authors, the prevalence of their early life history stages without adults suggest that young copepods in the river come from adjacent source areas and do not grow rapidly in the river.

Immature copepods appear particularly susceptible to downstream washout. Although at later developmental stages they exhibit progressively greater resistance to water flow, at immature stages they would have poor swimming ability, since these instars have poorly developed swimming appendages (Richardson, 1992). Thus, these immature instars often dominate densities of animals in drift in lotic environments (Saunders \& Lewis, 1989).

High concentration of suspended solids, resulting from high water turbulence in lotic environments directly affects zooplankton by obstructing filter and respiratory appendages, and indirectly affect it by reducing light penetration, thus decreasing primary productivity. Notwithstanding, the suspended solids could constitute alimentary sources, like detritus and bacterium. According to Carvalho (1983), the direct influence of suspended solid particles on zooplankton seems to affect only determinate populations, changing only species composition.

Current velocity has been considered one of the main environmental factors affecting abundance and even the existence of lotic zooplankton (Hynes, 1970). The majority of copepods showed negative correlation with current velocity, suspended solids, and dissolved oxygen, and positive correlation with water temperature. Similar results were obtained by Frutos (1998) in the Salado and Negro rivers
(Argentina), in which copepod nauplii were negatively correlated with suspended solids and positively correlated with temperature.

Increase of some copepods, specially calanoid nauplii and copepodids, toward the reservoir is probably due to lower current velocity and higher water temperature and transparency. This trend probably results in increased growth and reproduction rates of these organisms. Moreover, higher densities may also be related with zooplankton exportation from lateral lakes.

Studies on the effects of current velocities on distribution of copepods in lotic environments have shown that cyclopoids can exhibit relatively large populations due to their ability to resist and avoid flowing water. Moreover, organisms able to climb substrates should occur in greater densities than those that are strictly planktonic (Richardson, 1992). This could explain the higher densities of cyclopoids and harpacticoids in the Paranapanema River. Harpacticoids commonly found on stream beds are less likely to be exposed to flowing water since they inhabit the hyporheic zone, and their entry into the water column appears to be the result of complex interactions in which water velocity may be a controlling factor.

Longitudinal variations in composition, density, and distribution of communities are also affected by seasonal changes in environmental factors, due mainly to the hydrological regime. Variations of the hydrologic regime are undoubtedly of great importance, and responsible for main changes in a great number of environmental factors related to each other and to the zooplankton, such as flow, current velocity, turbidity, and suspended solids. Precipitation not only modifies the physical and chemical features of the environment, but also causes an increase in water level, increasing communication between the river system and the lateral associated environments.

According to Saunders \& Lewis (1988), changes in water level that cause lateral inundation tend to increase zooplankton abundance in the main channel. In the mouth of the Paranapanema River, copepods reached higher abundances in October (rainy season) when the connection between river and lakes is well established. High densities of copepods in high waters were also recorded by Lansac-Tôha et al. (1997) in lotic environments of 
the Upper Paraná River floodplain, and by Vasquez \& Rey (1989) in the Orinoco River and its delta (Venezuela).

In these upstream reaches of reservoirs, the interconnection between lateral lakes and the river system is strongly influenced by the hydrological level. Depending on the connection, these areas can act like reproduction or exportation areas. The copepod downstream transport toward the reservoir is mainly represented by young instars. Since these animals cannot develop in the river channel, downstream transport is an important factor in maintaining copepod community in the reservoir.

Acknowledgments - We thank Fapesp (Process 97/4999-8 thematic Process and 97/05610-7 - scholarship to the first author). We also thank Dr. Antônio C. S. Pião for the statistical analysis and Hamilton A. Rodrigues for field work and laboratory assistance.

\section{REFERENCES}

ARMENGOL, J., SABATER, F., RIEIRA, J. L. \& PUIG, M. A., 1988, Longitudinal changes in the zooplankton communities along a serie of reservoirs of Guadiana River (W. Spain). Verh. Internat. Verein. Limnol., 23: 1006-1010.

CARVALHO, M. L., 1983, Efeitos da flutuação do nível da água sobre a densidade e composição do zooplâncton em um lago de várzea da Amazônia, Brasil. Acta. Amazonica, 13(5-6): 715-724.

DRAGO, E. \& VASSALO, M., 1980, Campaña Limnológica "Keratella I" en el río Paraná Medio. Ecologia, 4: 45-54.

DUSSART, B. H., 1984, Some Crustacea Copepoda from Venezuela. Hydrobiologia, 113: 15-23.

FRUTOS, S. M., 1998, Densidad y diversidad del zooplancton en los ríos Salado y Negro - Planicie del río Paraná Argentina. Rev. Bras. Biol., 58(3): 431-444.

GOLTERMAN, K. L., CLYMO, R. S. \& OHNSTAD, M. A. M., 1978, Methods for physical and chemical analysis of freshwaters. 2. ed. IBP, Oxford, 213p.

GREENBERG, A. E., 1964, Plankton of the Sacramento River. Ecology, 45(1): 40-49.

HARDY, E. R., 1980, Composição do zooplâncton em cinco lagos da Amazônia Central. Acta. Amazonica, 10(3): 577609 .

HARDY, E. R., ROBERTSON, B. \& KOSTE, W., 1984, About the relationship between the zooplankton and fluctuating water levels of Lago Camaleão, a Central Amazonian várzea lake. Amazoniana IX, (1): 43-52

HUTCHINSON, L., 1939, Some factors influencing zoöplankton distribution in the Hocking River. Ohio J. Sci., 39: 259273.

HYNES, H. B. N., 1970, The Ecology of running waters. University Press, Liverpool, 555p.
JOSE DE PAGGI, S., 1983, Distribuición vertical del zooplancton en el río Paraná medio (km 603). Rev. Hydrobiol. Trop., 18(1): 13-21.

KOBAYASHI, T., SHIEL, R. J., GIBBS, P. \& DIXON, P. I., 1998 , Freshwater zooplankton in the Hawkesbury-Nepean River: comparison of community structure with other rivers. Hydrobiologia, 377: 133-145.

LANSAC-TÔHA, F. A., BONECKER, C. C., VELHO, L. F. M. \& LIMA, A. F., 1997, Composição, distribuição e abundância da comunidade zooplanctônica. In: A. E. A. M. Vazzoler, A. A. Agostinho \& N. S. Hahn, A planície de inundação do alto rio Paraná: aspectos fisicos, biológicos e socioeconômicos. EDUEM, pp. 117-155.

MACKERETH, F. I. H., HERON, J. \& TALLING, J. F., 1978, Water analysis: some revised methods for limnologists. Freshwater Biological Association, London, 121p.

MANLY, B. F. J., 1994, Multivariate statistical methods. Chapman \& Hall, London, 215p.

MARTINS, G. M., 2000, Diversidade e distribuição do zooplâncton em três lagoas laterais ao rio Paranapanema na zona de sua desembocadura na Represa de Jurumirim. Monografia, UNESP, 64p.

MATSUMURA-TUNDISI, T., 1986, Latitudinal distribution of Calanoida Copepods in freshwater aquatic systems of Brazil. Rev. Bras. Biol., 46 (3): 527-553.

NEIFF, J. J., 1996, Large rivers of South America: toward a new approach. Verh. Internat. Verein. Limnol., 26: 167-180.

NOGUEIRA, M. G., 2001, Zooplankton composition, dominance and abundance as indicators of environmental compartmentalization in Jurumirim reservoir (Paranapanema River), São Paulo, Brazil. Hydrobiologia, 455: 1-18.

NOGUEIRA, M. G. \& PANARELLI, E. A., 1997, Estudo da migração vertical das populações zooplanctônicas na Represa de Jurumirim (Rio Paranapanema - São Paulo, Brasil). Acta Limnol. Bras., 9: 55-81.

PAGGI, J. C. \& JOSE DE PAGGI, S., 1990, Zooplâncton de ambientes lóticos e lênticos do Rio Paraná Médio. Acta Limnol. Bras., 3: 685-719.

PANARELLI, E. A., NOGUEIRA, M. G. \& HENRY, R., 2001, Short-term variability of copepod abundance in Jurumirim Reservoir, São Paulo, Brazil. Braz. J. Biol., 61(4): 577-598.

REID, J. W., 1985, Chave de identificação e lista de referências bibliográficas para os táxons continentais sulamericanos de vida livre da ordem Cyclopoida (Crustacea, Copepoda). Bolm. Zool., 9: 17-143.

REID, J. W., 1988, Thermocyclops decipiens (Copepoda, Cyclopoida): exemplo de confusão taxonômica. Acta Limnol. Bras., 2: 479-499.

REID, J. W., 1989, The distribution of species of the genus Thermocyclops (Copepoda, Cyclopoida) in the western hemisphere, with description of $T$. parvus, new species. Hydrobiologia, 175: 149-174.

REID, J. W. \& MORENO, I. H., 1990, The Copepoda (Crustacea) of the southern Pantanal, Brazil. Acta Limnol. Brasil., 3: $721-740$. 
REID, J. W. \& PINTO-COELHO, R. M., 1994, An Afro-Asian continental copepod, Mesocyclops ogunnus, found in Brazil; with a new key to the species of Mesocyclops in South America and a review of introductions of copepods. Limnologica, 24: 359-368.

RICHARDSON, W. B., 1992, Microcrustacea in flowing water: experimental analysis of washout times and a field test. Freshwater Biology, 28: 217-230.

ROCHA, O. \& MATSUMURA-TUNDISI, T., 1976, Atlas do zooplâncton (Represa do Broa, São Carlos) I-Copepoda. Univ. Federal de São Carlos, Centro de Ciências e Tecnologia, $68 \mathrm{p}$.

SAUNDERS, J. F. III \& LEWIS, W. M. Jr., 1988, Zooplankton abundance in the Caura River, Venezuela. Biotropica, 20(3): 206-214

SAUNDERS, J. F. III \& LEWIS, W. M. Jr., 1989, Zooplankton abundance in the lower Orinoco River, Venezuela. Limnol. Oceanogr., 34(2): 397-409.

SENDACZ, S., 1993, Estudo da comunidade zooplanctônica de Lagoas Marginais do rio Paraná Superior. São Paulo, Ph.D. Thesis, Univ. São Paulo, 177p.

SENDACZ, S., 2001, Planktonic Copepoda of the Upper Paraná River Floodplain lakes (São Paulo and Mato Grosso do Sul, Brazil). Hydrobiologia, 453/454: 367-374.
SENDACZ, S. \& KUBO, E., 1982, Copepoda (Calanoida e Cyclopoida) de reservatórios do Estado de São Paulo. Bol. Inst. Pesca., 9: 51-89.

STEVENINCK, E. D. DE R. VAN, ADMIRAAL, W., BREEBAART, L., TUBBING, G. M. J. \& ZANTEN, B. VAN, 1992, Plankton in the River Rhine: structural and functional changes observed during downstream transport. J. Plank. Res., 14(10): 1351-1368.

TEIXEIRA, C. \& KUTNER, M. B., 1962, Plankton studies in a mangrove environment. I - First assessment of standing stock and ecological factors. Bol. Inst. Oceanogr., 12: 101-124.

VASQUEZ, E. \& REY, J., 1989, A longitudinal study of zooplankton along the Lower Orinoco River and its Delta (Venezuela). Annls Limnol., 25(2): 107-120.

VALDERRAMA, J. G., 1981, The simultaneous analysis of total nitrogen and phosphorous in natural waters. Mar. Chem., 10: 109-122.

VELHO, L. F. M., LANSAC-TÔHA, F. A., BONECKER, C. C., BINI, L. M. \& ROSSA, D. C., 2001, The longitudinal distribution of copepods in Corumbá Reservoir, State of Goiás, Brazil. Hydrobiologia, 453/454: 385-391.

WINNER, J. M., 1975, Zooplankton, pp. 155-169. In: B. A. Whitton (ed.), River ecology. Blackwell Scientific Publications, Oxford, 725p. 